\title{
Stability-Indicating Assay for the Determination of Pentobarbital Sodium in Liquid Formulations
}

\author{
Myriam Ajemni, Issa-Bella Balde, Sofiane Kabiche, Sandra Carret, Jean-Eudes Fontan, \\ Salvatore Cisternino, and Joël Schlatter
}

Service Pharmacie, AP-HP Hôpital Jean-Verdier, Hôpitaux Universitaires de Paris-Seine-Saint-Denis, Avenue du 14 juillet, 93140 Bondy, France

Correspondence should be addressed to Joël Schlatter; joel.schlatter@aphp.fr

Received 18 June 2015; Revised 25 September 2015; Accepted 27 September 2015

Academic Editor: Mohamed Abdel-Rehim

Copyright (C) 2015 Myriam Ajemni et al. This is an open access article distributed under the Creative Commons Attribution License, which permits unrestricted use, distribution, and reproduction in any medium, provided the original work is properly cited.

A stability-indicating assay by reversed-phase high performance liquid chromatography (RP-HPLC) method was developed for the determination of pentobarbital sodium in oral formulations: a drug used for infant sedation in computed tomography (CT) or magnetic resonance imaging (MRI) scan. The chromatographic separation was achieved on a reversed-phase C18 column, using isocratic elution and a detector set at $214 \mathrm{~nm}$. The optimized mobile phase consisted of a $0.01 \mathrm{M}$ potassium buffer $\mathrm{pH}$ 3 and methanol $(40: 60, \mathrm{v} / \mathrm{v})$. The flow rate was $1.0 \mathrm{~mL} / \mathrm{min}$ and the run time of analysis was $5 \mathrm{~min}$. The linearity of the method was demonstrated in the range of 5 to $250 \mu \mathrm{g} / \mathrm{mL}$ pentobarbital sodium solution $\left(r^{2}=0.999\right)$. The limit of detection and limit of quantification were 2.10 and $3.97 \mu \mathrm{g} / \mathrm{mL}$, respectively. The intraday and interday precisions were less than $2.1 \%$. Accuracy of the method ranged from 99.2 to $101.3 \%$. Stability studies indicate that the drug is stable to sunlight and in aqueous solution. Accelerated pentobarbital sodium breakdown by strong alkaline, acidic, or oxidative stress produced noninterfering peaks. This method allows accurate and reliable determination of pentobarbital sodium for drug stability assay in pharmaceutical studies.

\section{Introduction}

Pentobarbital sodium (5-ethyl-5-(1-methylbutyl)-2,4,6(1H, $3 \mathrm{H}, 5 \mathrm{H})$-pyrimidinetrione, sodium) is a psychoactive drug with short-acting sedative effects in adult and paediatric patients. However, it is not any longer marketed in Europe and in the United States. European drug agencies recently withdraw chloral hydrate, a widely used sedative drug, due to its adverse effects such as mutagenesis [1]. Pentobarbital sodium would be an alternative in paediatric sedative procedures such as in computed tomography or magnetic resonance imaging in infants. Clinical studies reported the effectiveness of pentobarbital sodium sedation and a decreased rate of adverse events as compared to chloral hydrate preimaging procedure [2-4]. Both drugs may also produce similar side effects including decreased oxygen saturation, vomiting, and respiratory depression [2-5]. The initial oral dose of sodium pentobarbital in sedation procedure for infants is usually $4-5 \mathrm{mg} / \mathrm{kg}$ with a maximum of $8 \mathrm{mg} / \mathrm{kg}$.
If the sedative response is not achieved, one additional $2 \mathrm{mg} / \mathrm{kg}$ oral dose can be administered [6]. A literature survey showed that only one liquid chromatography (HPLC) method is reported for the quantitative determination of pentobarbital sodium and some impurities in bulk drug substance and dosage forms with a chromatographic run of 30 min [7]. Drug crystallization could occur in $24 \mathrm{~h}$ when the pentobarbital sodium $50 \mathrm{mg} / \mathrm{mL}$ in $0.9 \%$ sodium chloride solution was further diluted to $10 \mathrm{mg} / \mathrm{mL}$ in repackaging polypropylene syringe [8]. More recently, Priest and Geisbuhler reported that injectable pentobarbital sodium was not degraded when stored in dark at room temperature using the HPLC method previously cited [9]. Here, we report a precise, accurate, and robust HPLC stability-indicating assay to assess pentobarbital sodium in oral/liquid compounding formulations which was validated for the first time with oxidative, alkali, and acidic breakdown and a chromatographic run time of $5 \mathrm{~min}$. This assay was validated according to the International Conference on Harmonization [10]. 


\section{Material and Method}

2.1. Chemical and Reagents. Pharmaceutical pentobarbital sodium powder was supplied by Inresa (Bartenheim, France, lot 10026/1111B479). Phenobarbital sodium was used as an internal standard (IS) and was obtained from Sanofi Whintrop (Maisons-Alfort, France, lot 284). The compounding formulations Inorpha, Ora-Plus, Ora-Sweet, Ora-Sweet SF, Ora-Blend, and Ora-Blend SF were purchased from Inresa (Bartenheim, France, lots 4388549, 4469317, 4378457, 4287617, 4509679 , and 4388553, resp.). The analytical grade methanol was obtained from Sigma-Aldrich (Chromasolv, St. Quentin Fallavier, France). Potassium dihydrogen phosphate was obtained from VWR Chemicals (Fontenay sous bois, France). Deionised water was purchased from Fresenius (Versylene, Sèvres, France).

2.2. HPLC Instrumentation and Conditions. The HPLC Dionex Ultimate 3000 system (Thermo Scientific, Villebon sur Yvette, France) contained an integrated solvent and degasser SRD-3200, an analytical pump HPG-3200SD, a thermostated autosampler WPS-3000TSL, a thermostated column compartment TCC-3000SD, and a diode array detector MWD3000. Data acquisition (e.g., peak time and area) was carried out using in line Chromeleon software (v6.80 SP2) (Thermo Scientific). The eluent was monitored at $214 \mathrm{~nm}$. Chromatographic separation was achieved at $25^{\circ} \mathrm{C}$ using a reverse phase Nova-Pak C18 column (60 A, $4 \mu \mathrm{m}, 4.6 \mathrm{~mm}$ $\times 150 \mathrm{~mm}$, Waters, Guyancourt, France). The mobile phase (0.01 M phosphate buffer $\mathrm{pH}$ 3: methanol; $40: 60 \mathrm{v} / \mathrm{v}$ ) was pumped at a flow rate of $1.0 \mathrm{~mL} / \mathrm{min}$. The injection volume was set at $25 \mu \mathrm{L}$.

\subsection{Preparation of Stock and Standards Solutions}

2.3.1. Pentobarbital Sodium Stock and Working Solutions. Pentobarbital sodium stock solution $(1 \mathrm{mg} / \mathrm{mL})$ was prepared by accurately weighing $100 \mathrm{mg}$. Volume was made up to the mark with deionised water in $100 \mathrm{~mL}$ volumetric flask. A working solution $(0.1 \mathrm{mg} / \mathrm{mL})$ was prepared by dilution of the stock solution. The solutions were stored at $2-8^{\circ} \mathrm{C}$ for 5 days.

2.3.2. Preparation of the Internal Standard Solution. Phenobarbital sodium stock solution $(1 \mathrm{mg} / \mathrm{mL})$ was prepared by accurately weighing $100 \mathrm{mg}$. Volume was made up to the mark with deionised water in $100 \mathrm{~mL}$ volumetric flask. The stock solution was stored at $2-8^{\circ} \mathrm{C}$ for 5 days.

2.3.3. Calibration Standards. Calibration standards at 5, 10, $20,50,100$, and $200 \mu \mathrm{g} / \mathrm{mL}$ were freshly prepared using either stock or working solution. These solutions contained IS at $20 \mu \mathrm{g} / \mathrm{mL}$.

2.3.4. Quality Control Samples. Quality control solutions at $8,15,30,80$, and $150 \mu \mathrm{g} / \mathrm{mL}$ containing IS $(20 \mu \mathrm{g} / \mathrm{mL})$ were prepared extemporaneously.

\subsection{Analytical Method Validation}

2.4.1. Linearity. Appropriate volumes of pentobarbital sodium stock $(1 \mathrm{mg} / \mathrm{mL})$ and working $(100 \mu \mathrm{g} / \mathrm{mL})$ standard solutions were diluted with deionised water to yield 5, 10, 20, 50,100 , and $200 \mu \mathrm{g} / \mathrm{mL}$. Six replicates of each concentration were independently prepared and injected into the chromatograph. The linearity was determined by calculating a regression line from the plot of the peak area ratios of the drug and IS versus concentrations of the drug. Regression analyses were computed for pentobarbital sodium with Chromeleon software. The method was evaluated by determination of the correlation coefficient and intercept values according to the ICH guidelines.

2.4.2. Limit of Detection and Limit of Quantification. Limit of detection (LOD) and limit of quantification (LOQ) of pentobarbital sodium assay were determined by calibration curve method. Solutions of pentobarbital sodium were prepared in linearity range and injected in triplicate. Average peak area of three analyses was plotted against concentration. LOD and LOQ were calculated by using the following equations: LOD $=\left(3.3 \times S_{y x}\right) / b, \mathrm{LOQ}=\left(10.0 \times S_{y x}\right) / b$, where $S_{y x}$ is residual variance due to regression; $b$ is the slope.

2.4.3. Precision. The intraday precision was determined by measuring quality control samples of $8,15,30,80$, and $150 \mu \mathrm{g} / \mathrm{mL}$ of pentobarbital sodium, injected six times on the same day. The intermediate precision was estimated by injecting quality control samples prepared at the same concentrations on three different days by different operators. The peak area ratios of all injections were taken and standard deviation, $\%$ relative standard deviation (RSD), was calculated.

2.4.4. Accuracy. Accuracy is tested by the standard addition method at different levels: $25,50,80,100$, and $120 \%$. The mean recovery of pentobarbital sodium of the target concentration $(50 \mu \mathrm{g} / \mathrm{mL})$ was calculated and accepted with $100 \pm 2 \%$.

2.4.5. Robustness. HPLC conditions were slightly modified to evaluate the analytical method robustness. These changes (see Table 1) included the flow rate, the detection wavelength, the column temperature, or the methanol proportion in the mobile phase.

2.4.6. Forced Degradation Study. Alkaline, acidic, and oxidative stress and direct exposure to sunlight were carried out as reported in Table 2. No internal standard was added in the forced degradation study.

(1) Alkali Hydrolysis. Ten mL of pentobarbital stock solution was mixed in a flask with $1 \mathrm{~N}$ sodium hydroxide $(4 \mathrm{~mL})$ for $1 \mathrm{~h}$ at $50^{\circ} \mathrm{C}$. Before analysis, the solution was cooled at room temperature and neutralized with hydrochloric acid. The solution was completed with deionised water to reach a targeted concentration of $50 \mu \mathrm{g} / \mathrm{mL}$ in a volumetric flask.

(2) Acid Hydrolysis. Ten mL of pentobarbital stock solution was mixed in a flask with $1 \mathrm{~N}$ hydrochloride acid $(4 \mathrm{~mL})$ 
TABLE 1: Robustness.

\begin{tabular}{|c|c|c|c|c|c|c|}
\hline Parameters & Modification & $\%$ recovery & $R_{s}$ & $T_{f}-\mathrm{D}$ & $T_{f}$-IS & Plates \\
\hline \multirow{3}{*}{ Flow rate $(\mathrm{mL} / \mathrm{min})$} & 1.1 & 100.3 & 8.06 & 1.30 & 1.34 & 5503 \\
\hline & 1.2 & 100.2 & 7.73 & 1.26 & 1.27 & 5155 \\
\hline & 1.3 & 100.2 & 7.46 & 1.19 & 1.38 & 4779 \\
\hline \multirow{3}{*}{ Wavelength of detection $(\mathrm{nm})$} & 218 & 105.0 & 8.46 & 1.27 & 1.42 & 6042 \\
\hline & 220 & 103.4 & 8.43 & 1.33 & 1.35 & 5969 \\
\hline & 225 & 78.5 & 8.41 & 1.31 & 1.42 & 5848 \\
\hline \multirow{3}{*}{ Column temperature $\left({ }^{\circ} \mathrm{C}\right)$} & 25 & 100.1 & 8.22 & 1.30 & 1.46 & 5828 \\
\hline & 27 & 100.1 & 8.02 & 1.35 & 1.34 & 5856 \\
\hline & 30 & 100.0 & 7.80 & 1.36 & 1.32 & 5944 \\
\hline \multirow{2}{*}{ Methanol in mobile phase } & $-0.2 \%$ & 100.0 & 8.42 & 1.33 & 1.38 & 6002 \\
\hline & $+0.2 \%$ & 100.0 & 7.33 & 1.39 & 1.42 & 5549 \\
\hline
\end{tabular}

$R_{s}$ : resolution; $T_{f}$-D: tailing factor of the drug; $T_{f}$-IS: tailing factor of the internal standard.

TABLE 2: Forced degradations studies.

\begin{tabular}{lccc}
\hline Stress conditions & \% remaining \% degradation & $\begin{array}{c}\text { Retention } \\
\text { time of } \\
\text { degraded } \\
\text { products }\end{array}$ \\
\hline $\begin{array}{l}\text { Acidic stress }(1 \mathrm{~N} \mathrm{HCl}, \\
\left.50^{\circ} \mathrm{C}, 1 \mathrm{~h}\right)\end{array}$ & 102.2 & - & 0.0 \\
$\begin{array}{l}\text { High acidic stress }(12 \mathrm{~N} \\
\left.\mathrm{HCl}, 50^{\circ} \mathrm{C}, 48 \mathrm{~h}\right)\end{array}$ & 31.8 & 68.2 & 0.0 \\
$\begin{array}{l}\text { Alkaline stress }(1 \mathrm{~N} \\
\left.\text { NaOH, } 50^{\circ} \mathrm{C}, 1 \mathrm{~h}\right)\end{array}$ & 98.4 & 1.6 & 0.0 \\
$\begin{array}{l}\text { High alkaline stress } \\
\left(10 \mathrm{~N} \text { NaOH, } 50^{\circ} \mathrm{C}, 48 \mathrm{~h}\right)\end{array}$ & 89.8 & 10.2 & $1.46,1.81$ \\
$\begin{array}{l}\text { Oxidative stress }(3 \%, \\
\left.50^{\circ} \mathrm{C}, 48 \mathrm{~h}\right)\end{array}$ & 50.9 & 49.1 & 1.44 \\
$\begin{array}{l}\text { Thermal stress }\left(50^{\circ} \mathrm{C}, 5\right. \\
\text { days })\end{array}$ & 89.4 & 10.6 & 0.0 \\
$\begin{array}{l}\text { High thermal stress } \\
\left(100^{\circ} \mathrm{C}, 1 \mathrm{~h}\right)\end{array}$ & 19.9 & 80.1 & 0.0 \\
$\begin{array}{l}\text { Direct sunlight }(48 \mathrm{~h}) \\
\text { Aqueous stability (after }\end{array}$ & 95.1 & 4.9 & 0.0 \\
21 days) & 99.7 & 0.3 & 0.0 \\
\hline
\end{tabular}

for $1 \mathrm{~h}$ at $50^{\circ} \mathrm{C}$. Before analysis, the solution was cooled at room temperature and neutralized with sodium hydroxide. The solution was completed with deionised water to reach a targeted concentration of $50 \mu \mathrm{g} / \mathrm{mL}$ in a volumetric flask.

(3) Oxidative Stress. Ten $\mathrm{mL}$ of the pentobarbital stock solution was mixed with $1 \mathrm{~mL}$ of $3 \%$ hydrogen peroxide and stored at $50^{\circ} \mathrm{C}$ for $1 \mathrm{~h}$. The solution was cooled and completed with deionised water until the volumetric flask mark to reach a targeted concentration of $50 \mu \mathrm{g} / \mathrm{mL}$.

(4) Sunlight Degradation. Ten $\mathrm{mL}$ of the pentobarbital stock solution was transferred into a $200 \mathrm{~mL}$ volumetric flask and exposed to direct sunlight for 5 days at room temperature.
The solution was completed to the flask mark with deionised water.

(5) Thermal Degradation. Ten $\mathrm{mL}$ of stock solution was transferred into volumetric flask $(200 \mathrm{~mL})$ and kept in air dry oven at $105^{\circ} \mathrm{C}$ for $5 \mathrm{~h}$. Then, the solution was cooled and completed to the flask mark with deionised water.

(6) Hydrolytic Degradation. Ten $\mathrm{mL}$ of pentobarbital stock solution was transferred into a volumetric flask and mixed with $10 \mathrm{~mL}$ of deionised water. The solution was heated on water bath for $1 \mathrm{~h}$. Then, the solution was cooled and completed until the $200 \mathrm{~mL}$ flask mark with water to reach a hypothetical target concentration of $50 \mu \mathrm{g} / \mathrm{mL}$.

\section{Results and Discussion}

3.1. Analytical Development Method. In order to achieve optimum separation, pentobarbital sodium and IS were injected into different mobile phase solutions mixing phosphate buffer and acetonitrile or phosphate buffer and methanol at different proportions, $70: 30,60: 40,50: 50$, and $40: 60$, and $\mathrm{pH}$ values, 7,5 , or 3 . The retention time and tailing factor along with resolution factor were recorded. As the $\mathrm{pKa}$ of pentobarbital is reported to be 8.1, mobile phase with $\mathrm{pH} 3$ was selected. Using the Nova-Pak C18 column, pentobarbital sodium and IS were eluted at 3.5 and $2.2 \mathrm{~min}$, respectively. Column temperature $\left(22-26^{\circ} \mathrm{C}\right)$ was found to be not a critical factor of this analysis. The optimum UV absorption of the drug was obtained at $214 \mathrm{~nm}$ as there was no interference from excipients present in oral compounding formulations. A typical chromatogram obtained with the present method is depicted in Figure 1.

\subsection{Method Validation}

3.2.1. Linearity. The linearity range of pentobarbital sodium was in the interval of $5-200 \mu \mathrm{g} / \mathrm{mL}$. These were represented by a mean linear regression equation as follows: $y=0.0291 x+$ 0.0378 with 0.9998 correlation coefficient and regression line was established by least squares method (Table 3 ). 
TABLE 3: Linearity data of the developed method.

\begin{tabular}{|c|c|c|c|c|c|}
\hline Initial conc. $(\mu \mathrm{g} / \mathrm{mL})$ & $\begin{array}{l}\text { Mean peak area } \pm \text { S.D. } \\
\text { (pentobarbital) }(n=6)\end{array}$ & $\begin{array}{l}\text { Mean peak area } \\
\text { (IS) }\end{array}$ & $\begin{array}{l}\text { Mean peak } \\
\text { ratio }\end{array}$ & $\begin{array}{c}\text { Actual conc. } \\
(\mu \mathrm{g} / \mathrm{mL})\end{array}$ & $\%$ assay \\
\hline 5 & $4.285 \pm 0.020$ & $27.805 \pm 0.192$ & $0.154 \pm 0.001$ & $3.99 \pm 1.29$ & 79.8 \\
\hline 10 & $8.637 \pm 0.050$ & $27.897 \pm 0.284$ & $0.310 \pm 0.001$ & $9.33 \pm 1.29$ & 93.3 \\
\hline 20 & $17.098 \pm 0.143$ & $27.186 \pm 1.093$ & $0.630 \pm 0.031$ & $20.34 \pm 1.19$ & 101.7 \\
\hline 50 & $42.565 \pm 1.147$ & $27.983 \pm 0.376$ & $1.521 \pm 0.028$ & $50.96 \pm 1.20$ & 101.9 \\
\hline 100 & $83.084 \pm 1.149$ & $27.856 \pm 0.111$ & $2.983 \pm 0.047$ & $101.19 \pm 1.14$ & 101.2 \\
\hline 200 & $164.194 \pm 0.401$ & $28.135 \pm 0.253$ & $5.836 \pm 0.048$ & $199.26 \pm 1.13$ & 99.6 \\
\hline \multicolumn{6}{|c|}{$y=0.0291 x+0.0378, r^{2}=0.9998$} \\
\hline
\end{tabular}

TABle 4: Precision study of the method.

\begin{tabular}{|c|c|c|c|c|c|c|}
\hline \multirow[b]{2}{*}{ Nominal conc. $(\mu \mathrm{g} / \mathrm{mL})$} & \multicolumn{3}{|c|}{ Intraday precision } & \multicolumn{3}{|c|}{ Interday precision } \\
\hline & $\begin{array}{c}\text { Calculated conc. } \\
(\mu \mathrm{g} / \mathrm{mL}), \text { mean } \pm \mathrm{SD}\end{array}$ & $\begin{array}{l}\text { Accuracy } \\
\text { (\%bias) }\end{array}$ & RSD & $\begin{array}{l}\text { Calculated conc. } \\
(\mu \mathrm{g} / \mathrm{mL}), \text { mean } \pm \mathrm{SD}\end{array}$ & $\begin{array}{l}\text { Accuracy } \\
\text { (\%bias) }\end{array}$ & RSD \\
\hline 8 & $8.273 \pm 0.009$ & 3.42 & 0.11 & $8.181 \pm 0.103$ & 2.27 & 1.25 \\
\hline 15 & $15.280 \pm 0.143$ & 1.86 & 0.94 & $15.052 \pm 0.208$ & 0.35 & 1.38 \\
\hline 30 & $30.748 \pm 0.632$ & 2.49 & 2.06 & $30.355 \pm 0.386$ & 1.18 & 1.27 \\
\hline 80 & $81.738 \pm 0.602$ & 2.17 & 0.74 & $81.257 \pm 1,218$ & 1.57 & 1.50 \\
\hline 150 & $153.569 \pm 0.328$ & 2.38 & 0.21 & $152,278 \pm 2,139$ & 1.52 & 1.41 \\
\hline
\end{tabular}

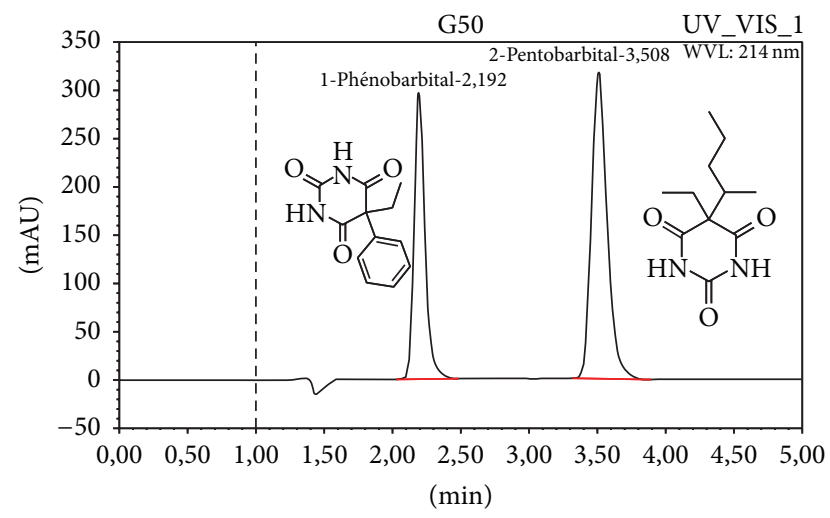

FIGURE 1: Typical chromatogram of pentobarbital sodium and internal standard and their chemical structures.

3.2.2. Limit of Detection (LOD) and Limit of Quantification (LOQ). The determined values of LOD and LOQ were 2.103 and $3.979 \mu \mathrm{g} / \mathrm{mL}$ calculated using slope and Y-intercept as per ICH guideline.

3.2.3. Precision. The results were obtained for the intraday and interday precision of the method, expressed as RSD values. As shown in the table, the intraday and interday RSD were $<2.1 \%$ for all concentrations tested in different situations studied (Table 4$)$.

3.2.4. Accuracy. The percentage recoveries were found to be 99.2 to $101.3 \%$ (Table 5). The results of the recovery studies undoubtedly demonstrate accuracy of the proposed method.
TABLE 5: Accuracy of the method.

\begin{tabular}{lccccc}
\hline $\begin{array}{l}\text { Standard } \\
(\mu \mathrm{g} / \mathrm{mL})\end{array}$ & \multicolumn{2}{c}{ Added } & Found $(\mu \mathrm{g} / \mathrm{mL})$ & $\begin{array}{c}\text { \% recovery } \\
\text { RSD }\end{array}$ \\
\hline 50 & 25 & 62.5 & $63.29 \pm 0.48$ & $101.27 \pm 0.77$ & 0.77 \\
50 & 50 & 75 & $74.78 \pm 0.56$ & $99.71 \pm 0.75$ & 0.75 \\
50 & 80 & 90 & $89.55 \pm 2.61$ & $99.49 \pm 2.90$ & 2.90 \\
50 & 100 & 100 & $99.23 \pm 1.22$ & $99.23 \pm 1.22$ & 1.22 \\
50 & 120 & 110 & $110.59 \pm 0.28$ & $100.53 \pm 0.25$ & 0.25 \\
\hline
\end{tabular}

3.2.5. Specificity. The specificity was estimated by spiking compounding vehicles as Ora-Plus, Ora-Sweet, Ora-Sweet SF, Ora-Blend, Ora-Blend SF, and Inorpha into a preweighed quantity of drug. The specificity study was carried out to check the interference from the excipients used in these vehicles. The chromatogram showed peak for pentobarbital sodium without any interfering peak.

3.2.6. Robustness. The robustness of the method was illustrated by getting the resolution $\left(R_{s}\right)$, the tailing factor of the drug $\left(T_{f}-\mathrm{D}\right)$, the tailing factor of the internal standard $\left(T_{f^{-}}\right.$ IS), and the number of plates when flow rate, wavelength detection, column temperature, and methanol proportion were slightly changed (Table 1 ). Table 1 shows that the percent recoveries of pentobarbital sodium were good under most conditions except for the wavelength condition at $225 \mathrm{~nm}$. The deliberate changes in the method do not affect the resolution, tailing factors of drug and IS, and number of plates significantly (Table 1). 


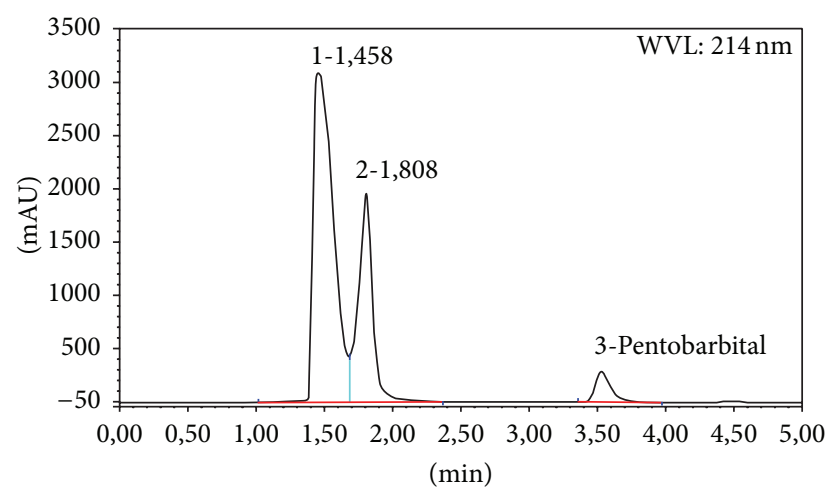

FIGURE 2: Chromatogram of $12 \mathrm{~N} \mathrm{NaOH}$ treated pentobarbital sodium at $50^{\circ} \mathrm{C}$ for $48 \mathrm{~h}$.

3.2.7. System Suitability Parameters. The system suitability tests were studied before performing the validation and the calculated parameters are within the acceptance criteria. The capacity factor was 1.39 , the resolution was 7.65 , the selectivity was 1.6, the number of theoretical plates was 5550, the tailing factor $\left(T_{f}-\mathrm{D}\right)$ of drug was 1.30 , the tailing factor of internal standard ( $T_{f}$-IS) was 1.35 , and the RSD of repeatability of injection were $<0.3 \%$. Hence, the proposed method was successfully applied to routine analysis.

3.2.8. Stability of Sample. Stability of the sample solution was established by storage of the sample solution at refrigerator $\left(2-8^{\circ} \mathrm{C}\right)$ for 21 days and at room temperature for $24 \mathrm{~h}$. The results from the solution stability experiments confirmed that the sample solution was stable for up to 21 days at refrigerator and during assay determination.

3.2.9. Forced Degradation Study. Forced degradation studies were performed to demonstrate the stability-indicating capability of the proposed HPLC method (Table 2). No degradation of pentobarbital sodium exposed to $1 \mathrm{~N} \mathrm{HCl}$, $1 \mathrm{~N} \mathrm{NaOH}$, and direct sunlight was observed. Due to this particular stability, high acidic and alkaline stress conditions were performed using $10 \mathrm{~N} \mathrm{NaOH}$ and $12 \mathrm{~N} \mathrm{HCl}$ at $50^{\circ} \mathrm{C}$ for $48 \mathrm{~h}$. A chromatogram of high alkaline hydrolysis performed at $50^{\circ} \mathrm{C}$ for $48 \mathrm{~h}$ showed degradation product peaks at retention times 1.46 and $1.81 \mathrm{~min}$ (Figure 2). A chromatogram of oxidative stress performed at $50^{\circ} \mathrm{C}$ for $48 \mathrm{~h}$ showed degradation product peak at retention time 1.44 min (Figure 3 ). The compound was stable at high temperature $\left(50^{\circ} \mathrm{C}\right)$ and in aqueous solution. These statements are in agreement with the $6.5 \%$ loss of potency described by Gupta [8] in its pentobarbital preparation boiled for $1.5 \mathrm{~h}$ and the complete degradation of pentobarbital in 30 days using combination of high $\mathrm{pH}$ and $20 \%$ formaldehyde described by Gannet et al. [11].

\section{Conclusion}

This rapid and simple RP-HPLC method was successfully developed for the determination of pentobarbital sodium stability in water solution. The developed analytical method is

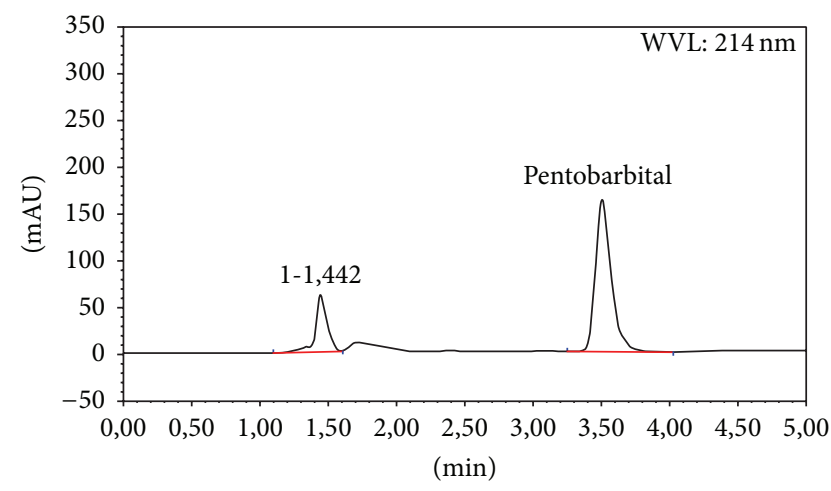

FIGURE 3: Chromatogram of 3\% hydrogen peroxide treated pentobarbital sodium at $50^{\circ} \mathrm{C}$ for $48 \mathrm{~h}$.

precise, accurate, and linear. Forced degradation data proved that the method is specific for the analyte and free from the interference of blank and unknown degradation products. The method is suitable for the analysis of stability samples and the routine analysis of pentobarbital sodium in formulations.

\section{Conflict of Interests}

The authors declare that there is no conflict of interests regarding the publication of this paper.

\section{References}

[1] Agence nationale de sécurité du médicament et des produits de santé (ANSM), June 2015, http://ansm.sante.fr/var/ansm_site/ storage/original/application/3a34fdaaa36cd5e9e695cfb96a5833fb .pdf.

[2] V. E. Karian, P. E. Burrows, D. Zurakowski, L. Connor, and K. P. Mason, "Sedation for pediatric radiological procedures: analysis of potential causes of sedation failure and paradoxical reactions," Pediatric Radiology, vol. 29, no. 11, pp. 869-873, 1999.

[3] K. L. Napoli, C. G. Ingall, and G. R. Martin, "Safety and efficacy of chloral hydrate sedation in children undergoing echocardiography," Journal of Pediatrics, vol. 129, no. 2, pp. 287-291, 1996.

[4] S. B. Greenberg, E. N. Faerber, C. L. Aspinall, and R. C. Adams, "High-dose chloral hydrate sedation for children undergoing MR imaging: safety and efficacy in relation to age," American Journal of Roentgenology, vol. 161, no. 3, pp. 639-641, 1993.

[5] C. J. Coté, H. W. Karl, D. A. Notterman, J. A. Weinberg, and C. McCloskey, "Adverse sedation events in pediatrics: analysis of medications used for sedation," Pediatrics, vol. 106, no. 4, pp. 633-644, 2000.

[6] C. N. Warden, P. K. Bernard, and T. R. Kimball, “The efficacy and safety of oral pentobarbital sedation in pediatric echocardiography," Journal of the American Society of Echocardiography, vol. 23, no. 1, pp. 33-37, 2010.

[7] J. A. Morley and L. Elrod Jr., "Determination of pentobarbital and pentobarbital sodium in bulk drug substance and dosage forms by high-performance liquid chromatography," Journal of Pharmaceutical and Biomedical Analysis, vol. 16, no. 1, pp. 119129, 1997.

[8] V. D. Gupta, "Stability of pentobarbital sodium after reconstitution in $0.9 \%$ sodium chloride injection and repackaging 
in glass and polypropylene syringes," International Journal of Pharmaceutical Compounding, vol. 5, no. 6, pp. 482-484, 2001.

[9] S. M. Priest and T. P. Geisbuhler, "Injectable sodium pentobarbital: stability at room temperature," Journal of Pharmacological and Toxicological Methods, vol. 76, pp. 38-42, 2015.

[10] International Conference of Harmonization, ICH Harmonised Tripartite Guideline: Validation of Analytical Procedures: Text and Methodology, Q2(R1), ICH, Geneva, Switzerland, 2005, http://www.ich.org/fileadmin/Public_Web_Site/ICH_Products/ Guidelines/Quality/Q2_R1/Step4/Q2_R1_Guideline.pdf.

[11] P. M. Gannett, J. R. Daft, D. James, B. Rybeck, J. B. Knopp, and T. S. Tracy, "In vitro reaction of barbiturates with formaldehyde," Journal of Analytical Toxicology, vol. 25, no. 6, pp. 443-449, 2001. 

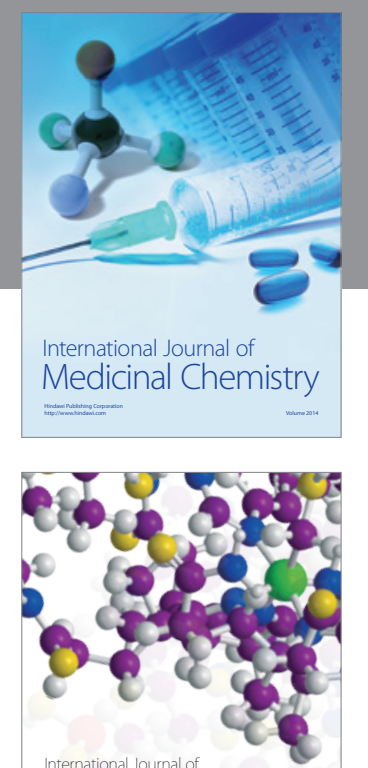

\section{Carbohydrate} Chemistry

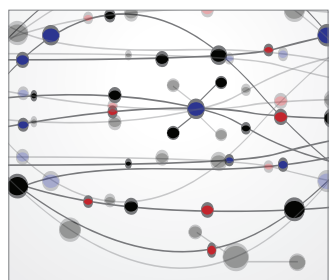

The Scientific World Journal
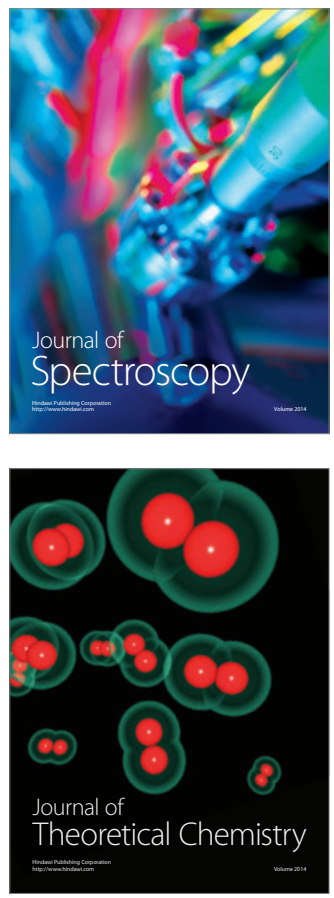
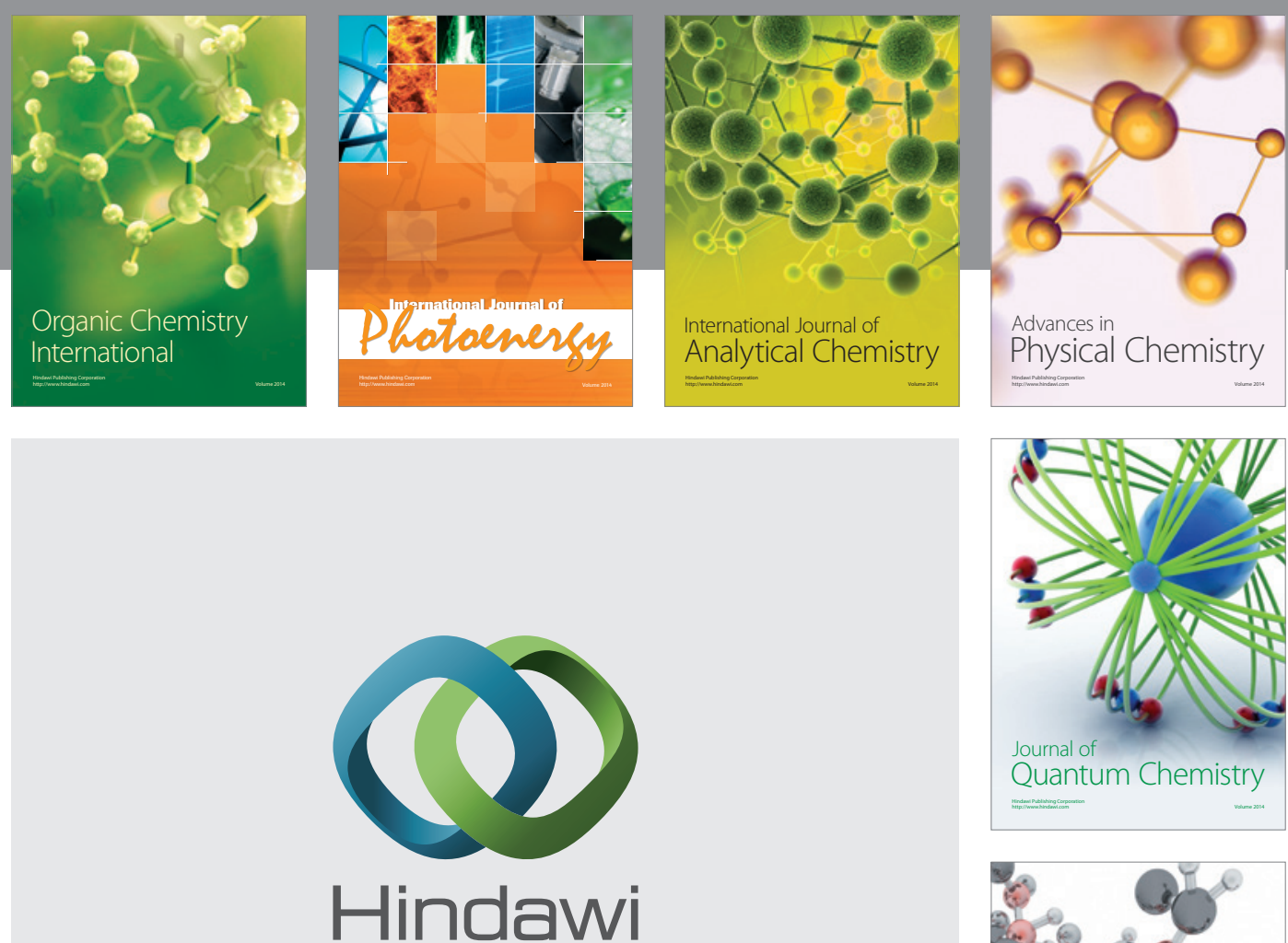

Submit your manuscripts at

http://www.hindawi.com

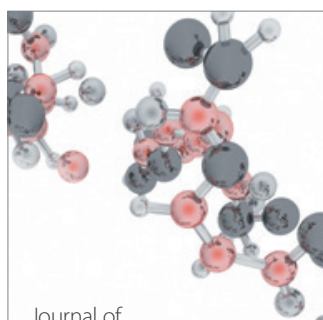

Analytical Methods

in Chemistry

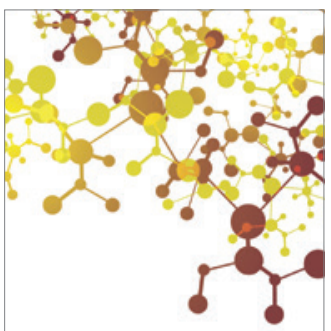

Journal of

Applied Chemistry

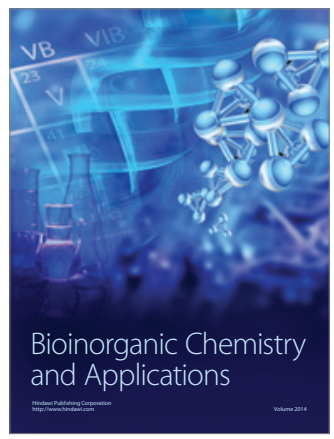

Inorganic Chemistry
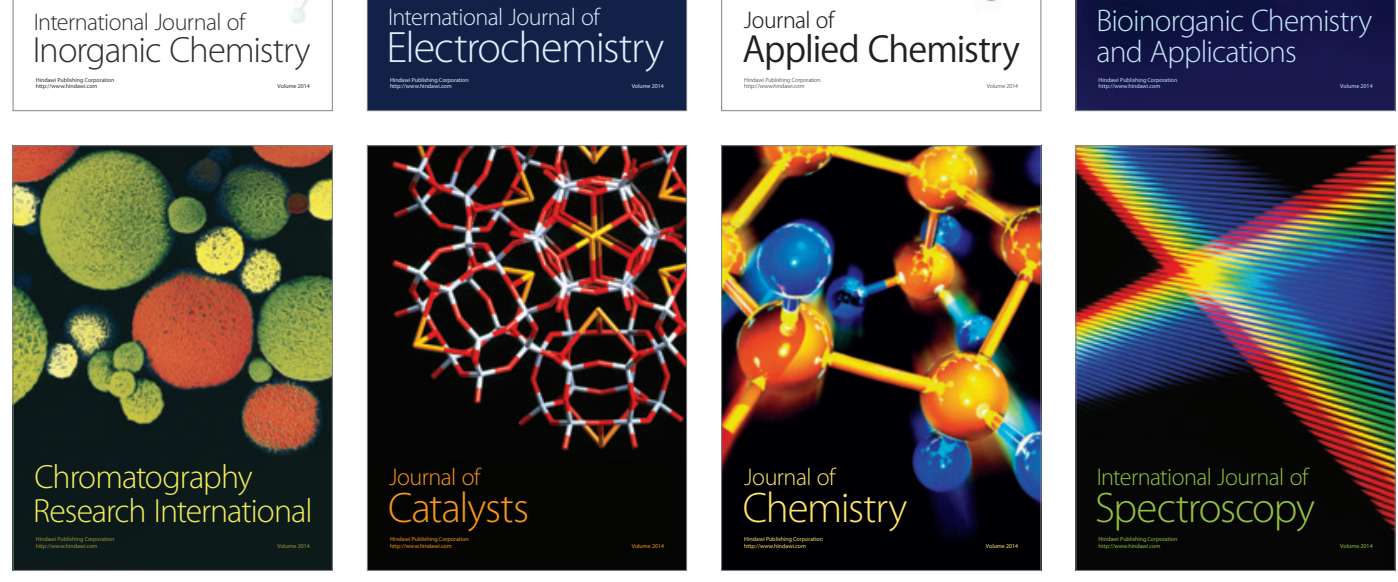